\title{
MYCOFLORA AND AFLATOXIN/FUMONISIN PRODUCTION BY FUNGAL ISOLATES FROM FRESHLY HARVESTED CORN HYBRIDS
}

\author{
Adriana P. Almeida ${ }^{1 *}$; Benedito Corrêa ${ }^{1}$; Marisa A. B. Mallozzi² ${ }^{2}$ Eduardo Sawazaki $^{3}$; Lúcia M. Valente Soares ${ }^{4}$ \\ ${ }^{1}$ Instituto de Ciências Biomédicas, Departamento de Microbiologia, Universidade de São Paulo, São Paulo, SP, Brasil. ${ }^{2}$ Instituto \\ Biológico de São Paulo; São Paulo, SP, Brasil. ${ }^{3}$ Instituto Agronômico de Campinas, Campinas, SP, Brasil. ${ }^{4}$ Faculdade de \\ Engenharia de Alimentos, Universidade Estadual de Campinas, Campinas, SP, Brasil.
}

Submitted: March 17, 2000; Returned to authors for corrections: June 15, 2000; Approved: October 20, 2000

\begin{abstract}
The mycoflora of 3 hybrids of freshly harvested corn grains collected from three regions of the state of São Paulo, Brazil (Assis, Capão Bonito and Ribeirão Preto) was investigated. A total of 66 samples were analyzed focusing on the influence of abiotic factors (moisture content, water activity, temperature and rainfall) on both the prevalence of Aspergillus flavus and Fusarium moniliforme, and the ability of these genera isolates to produce aflatoxins and fumonisins, respectively. In the three surveyed regions, the fungal population comprised mainly Fusarium spp., Penicillium spp., Aspergillus spp. and 2 others filamentous fungal genera, which were isolated from corn kernels showing water activity of 0.30 to 0.99 and moisture content of 5.0\% to 20.2\%. Among the genera Fusarium and Aspergillus, the most frequent species were F. moniliforme and A. flavus, respectively. Concerning the toxigenic potential of $F$. moniliforme, all isolated strains (40) produced fumonisins at $20 \mu \mathrm{g} / \mathrm{g}$ to $2168 \mu \mathrm{g} / \mathrm{g}\left(\mathrm{FB}_{1}\right)$ and $/$ or $10 \mu \mathrm{g} / \mathrm{g}$ to $380 \mu \mathrm{g} / \mathrm{g}\left(\mathrm{FB}_{2}\right)$. From the $10 \mathrm{~A}$. flavus isolates, 6 strains $(60.0 \%)$ produced aflatoxins at $615 \mu \mathrm{g} / \mathrm{kg}$ to $30.750 \mu \mathrm{g} / \mathrm{kg}\left(\mathrm{AFB}_{1}\right)$ and $/$ or $11 \mu \mathrm{g} / \mathrm{kg}$ to $22 \mu \mathrm{g} / \mathrm{kg}\left(\mathrm{AFB}_{2}\right)$.
\end{abstract}

Key words: aflatoxins, Aspergillus flavus, fumonisins, Fusarium moniliforme, corn

\section{INTRODUCTION}

The corn in Brazil has an important role in both human and animal nutrition, and has been ranked as the third world producer following the USA and China. Recently, the Brazilian annual corn yield reached 32 tons (32), of which $41 \%$ was used for poultry and swine consumption, where approximately $24.7 \%$ is directly used in farms, produced significantly by small producers (26).

The mean productivity of $2.747 \mathrm{~kg}$ corn/ha recorded in the state of São Paulo in 1990-94 reflects a poor local technology (31). The corn fields in this state correspond to $7 \%$ of cultivated land and cover a mean area of 13.28 ha (10); $61.93 \%$ of the farmers receive technical assistance, $44.14 \%$ use soil analysis, and $46.23 \%$ use hybrid grains (10).

Grain spoilage reduces the nutritional value of cereals, resulting in world losses of foodstuff in 5\% (14). Improved storage conditions can rise $10-20 \%$ in the supply of foodstuffs (8), as in Brazil, losses of $10 \%$ (26) to $25 \%$ (6) occurs during trading.

Fungi are worldwide microorganism, although tropical climates favor the growth of toxigenic species on agricultural products, with consequent risk of mycotoxin contamination (12). Therefore, as local agricultural practices and storage characteristics can be expected to create optimal growth conditions for specific toxigenic fungi, the need for regional investigations on these parameters cannot be neglected. The aim of this work was to evaluate the contamination risk of corn cultivated in the state of São Paulo, Brazil, by studying the mycoflora of three hybrids in three different regions, focusing on the influence of abiotic factors (moisture content, water activity, temperature and rainfall) on the prevalence of fungal species as well as the ability of Aspergillus flavus and Fusarium moniliforme isolates to produce aflatoxins and fumonisins, respectively.

\footnotetext{
* Corresponding author. Mailing address: Instituto de Ciências Biomédicas II, Departamento de Microbiologia, Universidade de São Paulo, Av. Prof Lineu Prestes, 1374, Cidade Universitária, CEP 05508-900, São Paulo - SP, Brasil. Fax: (+5511) 3818-7354. E-mail: correabe@usp.br.
} 


\section{MATERIALS AND METHODS}

\section{Grain samples}

Three corn cultivars (hybrids BR-201, C-901 and CX-322) of 1995 crop were selected according the harvest period required from seeding to harvest. The hybrids were cultivated in three regions of the state of São Paulo: Assis (22 $40^{\circ}$ latitude, $50^{\circ} 28^{\prime}$ longitude), Capão Bonito ( $24^{\circ} 02^{\prime}$ latitude, $48^{\circ} 22^{\prime}$ longitude) and Ribeirão Preto ( $22^{\circ} 11^{\prime}$ latitude, $47^{\circ} 48^{\prime}$ longitude), Brazil. Sixty six samples were analyzed, 30 of which were from Assis, 18 from Capão Bonito and 18 from Ribeirão Preto.

\section{Moisture content and water activity}

The moisture content of the corn grains was determined in the storage "in loco" immediately after sampling, using a "Brow Duvel" moisture meter (Model CA 25II, Gehaka Co.). Water activity was determined by automated analysis using AQUALAB CX-2 (Decagon Devices Inc.). Each sample was measured five times.

\section{Recovery, identification and enumeration of the mycoflora (5)}

Ten grams of sampled corn was ground and mixed with $90 \mathrm{ml}$ of sterile distilled water, followed by ten fold serial dilutions up to $10^{-4}$. Duplicate $1 \mathrm{ml}$ volumes of each dilution were added to Petri dishes containing 10 to $15 \mathrm{ml}$ of Potato Dextrose Agar (PDA); the plates were incubated at $25^{\circ} \mathrm{C}$ for 5 days and observed daily. Plates that contained 15 to $150 \mathrm{CFU}$ were used for counting and the results were expressed as CFU per gram of sample. The fungal colonies recovered were identified according to methods recommended for each genus $(2,22,28)$.

\section{Toxicity of $\boldsymbol{F}$. moniliforme strains}

One $\mathrm{ml}$ spore suspensions of $F$. moniliforme strains cultured in Sabouraud Dextrose Agar (SDA) at $25^{\circ} \mathrm{C}$ were inoculated into Erlenmeyer flasks containing $50 \mathrm{~g}$ of sterilized rice. The Erlenmeyer flasks were incubated for 15 days at $25^{\circ} \mathrm{C}$, followed by another period of 15 days at $15^{\circ} \mathrm{C}$. The rice samples were then tested for fumonisins according to the method of ORSI et al. (25). Briefly, 10 grams of rice cultures were added to $50 \mathrm{ml}$ of acetonitrile/water $(1: 1)$ and stirred for 30 minutes. The extract was filtered, $2 \mathrm{ml}$ of the filtrate was added to $5 \mathrm{ml}$ of water and the mixture was applied to a preconditioned Sep-pak C-18 cartridge (Waters, Division of Millipore, Milfort MA). The cartridge was washed with $2 \mathrm{ml}$ of acetonitrile/water (20:80) and the toxin eluted with $2 \mathrm{ml}$ of acetonitrile/water (70:30). The final extract was collected in Eppendorf tubes and stored at $-20^{\circ} \mathrm{C}$ until use.

Two hundred microliters of the final extract were derivatized with $50 \mu 1$ of o-phthaldialdehyde (OPA) (40 mg of OPA dissolved in $1 \mathrm{ml}$ of methanol and diluted in $5 \mathrm{ml}$ of $0.1 \mathrm{M}$ sodium tetraborate containing $50 \mu \mathrm{l}$ of mercaptoethanol). The reaction product was analyzed by a reverse-phase isocratic HPLC system consisting of a Shimadzu SCL-6B pump, an RF55 fluorescent detector (Shimadzu; excitation and emission wavelength of 355 and 440 , respectively) and a $150 \times 4.6 \mathrm{~mm}$ C18 column (50DS-20, Phenomenex). The eluent was methanol/ sodium acetate buffer $(77: 23) \mathrm{pH}$ 3.6. Calibration of the apparatus was made using solutions of standard fumonisins (Sigma) at the concentrations of $0.0125,0.025$ and $0.05 \mu \mathrm{g} / \mathrm{ml}$ for $\mathrm{FB}_{1}$ and $0.005,0.01$ and $0.02 \mu \mathrm{g} / \mathrm{ml}$ for $\mathrm{FB}_{2}$. A recovery test was conducted in quadruplicates at levels that ranged from 4 to $24 \mathrm{ng}$ of $\mathrm{FB}_{1}$ and 8 to $56 \mathrm{ng}$ of $\mathrm{FB}_{2}$ per $\mathrm{g}$ of ground corn. The recoveries of $\mathrm{FB}_{1}$ and $\mathrm{FB}_{2}$ were $88 \%$ and $94 \%$, respectively. The detection limit was $50 \mathrm{ng} / \mathrm{g}$ for both $\mathrm{FB}_{1}$ and $\mathrm{FB}_{2}$, with a minimum detectable concentration of $10 \mathrm{ng} / \mathrm{g}$.

\section{Toxicity of $\boldsymbol{A}$. flavus strains}

A small fragment of $A$. flavus colony in SDA at $25^{\circ} \mathrm{C}$ was inoculated on the center of a Petri dish with Coconut Agar (21). Incubation was carried out at $25^{\circ} \mathrm{C}$ for 10 days, and the cultures were assayed for aflatoxins as describe by Lin and Dianese (21). The Coconut Agar cultures were extracted with chloroform ( $30 \mathrm{ml}$ chloroform per $10 \mathrm{~g}$ culture) by shaking for 30 minutes. The content was filtered through a Whatman \#1 filter paper and evaporated to dryness. The suspended extracts were quantified by thin-layer chromatography (TLC) using standard aflatoxins (Sigma) (1).

\section{Climatic data}

Temperature $\left({ }^{\circ} \mathrm{C}\right)$ and rainfall $(\mathrm{mm})$ were recorded as monthly averages by the Agronomic Institutes of Assis, Capão Bonito and Ribeirão Preto.

\section{Statistical analysis $(9,30)$}

The statistical analysis of the data was performed in two stages, using the Statistical Software SAS (SAS Institute, 1985):

1) In the preliminary analysis the variables were selected accounting the growth of Fusarium spp., which can also indicate differences between hybrids per region. To determine the multiple regression model, simple correlation and partial correlation analyses were performed, so as to describe the nature of the relationship between the dependent variable (Fusarium spp growth) and the independent variables (water activity, moisture content, mean temperature and rainfall). Next, the multiple linear regression model was determined taking into account all the variables of the experiment. Variables were then selected by the Stepwise Method and a residual analysis of the chosen model was performed. The analysis of parallel lines was applied in order to test for possible differences between hybrids per region.

2) In a second stage, a comparison of means was performed to analyze, for each hybrid, the effect of regions on Fusarium spp. growth. 


\section{RESULTS AND DISCUSSION}

The analysis of 66 samples of freshly harvested corn grains (hybrids BR-201, C-901 and CX-322) collected in three regions of the state of São Paulo revealed the following compositions of fungal microbiota: Region of Assis, - Fusarium spp. (80.0\%), Penicillium spp. (40.0\%) Aspergillus spp. (23.3\%) and Geotrichum spp. (23.3\%); Region of Capão Bonito, - Fusarium spp. (55.5\%), Penicillium spp. (50.0\%), Geotrichum spp. (38.9\%) and Aspergillus spp. (22.2\%); Region of Ribeirão Preto, Fusarium spp. (77.8\%), Penicillium spp. (50.0\%) and Non Sporulated Fungi (5.5\%) (Table 1).

The predominance of Fusarium spp., Aspergillus spp. and Penicillium spp. in freshly harvested corn grains was also shown by Lillehoj and Zuber (20) in a work carried out with samples from different countries. Julian et al. (15) reported similar findings on corn from Honduras, as González et al. (11) in corn from five different regions of Argentina.

The Fusarium spp. frequencies, shown in Table 1, agree with data reported by other workers $(7,17,24,27)$, whom describe this genus as the most prevalent filamentous fungus in freshly harvested Brazilian corn. At the species level, 60.6\% were identified as F. moniliforme and $9.1 \%$ as F. subglutinans.

Among the Aspergillus isolates, the species identified were A. flavus (15.1\%) and A. glaucus (3.0\%). The presence of $A$. flavus in freshly harvested corn was previously observed $(17,18,19)$. Although Aspergillus spp. has been typically considered a storage fungus, these findings demonstrate its field occurrence.

The high frequency of $F$. moniliforme $(60.6 \%)$ and $A$. flavus $(15.1 \%)$ in the samples surveyed in our work emphasizes the importance of research on fumonisin and aflatoxin

Table 1: Absolute and relative frequencies ( $\%$ of fungi isolated from 66 samples of freshly harvested corn samples (hybrids BR-201, C-901 and CX-322) in Assis (30), Capão Bonito (18) and Ribeirão Preto (18) during February to December 1995 (State of São Paulo, Brazil).

\begin{tabular}{lcccccc}
\hline \multirow{2}{*}{ Fungus } & \multicolumn{7}{c}{ Planted Area } \\
& $\mathrm{AF}^{\mathrm{a}}$ & $\mathrm{RF}^{\mathrm{b}}$ & $\mathrm{AF}$ & $\mathrm{RF}$ & $\mathrm{AF}$ & $\mathrm{RF}$ \\
\hline Fusarium spp. & 24 & 80.0 & 10 & 55.5 & 14 & 77.8 \\
Aspergillus spp. & 7 & 23.3 & 4 & 22.2 & 0 & 0.0 \\
Penicillium spp. $^{2}$ & 12 & 40.0 & 9 & 50.0 & 9 & 50.0 \\
Feotrichum spp. $^{\text {A. }}$ & 7 & 23.3 & 7 & 38.9 & 0 & 0.0 \\
N.S.F. $^{\text {c }}$ & 0 & 0.0 & 0 & 0.0 & 1 & 5.5 \\
\hline
\end{tabular}

a Absolute Frequency;

${ }^{\mathrm{b}}$ Relative Frequency;

c Non-sporulated fungi. contamination of freshly harvested corn. The presence and extent of fungal growth not only can indicate what mycotoxin is to be expected but also may point to adequate strategies for prevention of toxin production (23).

The results on CFU/g (Table 2) showed that Fusarium spp. prevailed in all the samples, with maximum values of $3.6 \times 10^{6}$ in Assis, $4.8 \times 10^{5}$ in Capão Bonito and $1.7 \times 10^{6}$ in Ribeirão Preto; these numbers stand above the tolerance limits $\left(10^{2}\right.$ to $10^{4} \mathrm{CFU} /$ g) recommended by the International Commission on Microbiological Specification for Foods (13). The highest Aspergillus spp and Fusarium spp. counts were detected in samples from Assis; on the other hand, Penicillium spp. was detected as the main contaminant of corn grains from Capão Bonito.

The fungal isolates were recovered from corn with moisture content (MC) and water activity $\left(\mathrm{a}_{\mathrm{w}}\right)$ at $5.0 \%$ to $20.2 \%$ and 0.30 to 0.99 , respectively (Table 3 ). The highest frequencies of the three major toxigenic genera were detected in grains with $\mathrm{a}_{\mathrm{w}}$ of 0.60 to 0.70 and $\mathrm{MC} 10 \%$ to $12 \%$, which are values considered adequate for corn trading in Brazil (3).

Table 2: Total counts of Fusarium, Aspergillus and Penicillium recovered from 66 samples of freshly harvested corn sampled in Assis, Capão Bonito and Ribeirão Preto (State of São Paulo, Brazil).

\begin{tabular}{lccc}
\hline \multicolumn{4}{c}{ Fusarium spp. } \\
\hline Region & \multicolumn{3}{c}{ CFU/g ${ }^{\mathrm{a}} \times 10^{4}$} \\
& BR-201 & $\mathrm{C}-901$ & $\mathrm{CX}-322$ \\
\hline Assis & 400.0 & 418.0 & 1108.0 \\
Capão Bonito & 65.0 & 49.0 & 45.0 \\
Ribeirão Preto & 312.0 & 442.0 & 448.0 \\
\hline
\end{tabular}

Aspergillus spp.

\begin{tabular}{lccc}
\hline Region & \multicolumn{3}{c}{ CFU/g x 10 } \\
& BR-201 & C-901 & CX-322 \\
\hline Assis & 86.0 & 200.0 & 19.0 \\
Capão Bonito & 7.0 & 6.0 & 4.0 \\
Ribeirão Preto & ND $^{\mathrm{b}}$ & $\mathrm{ND}^{\mathrm{b}}$ & $\mathrm{ND}^{\mathrm{b}}$ \\
\hline
\end{tabular}

Penicillium spp.

\begin{tabular}{lccc}
\hline Region & \multicolumn{3}{c}{ CFU/g x 10 } \\
& BR-201 & C-901 & CX-322 \\
\hline Assis & 64.0 & 24.0 & 9.0 \\
Capão Bonito & 13.0 & 83.0 & 37.0 \\
Ribeirão Preto & 14.0 & 15.0 & 14.0 \\
\hline
\end{tabular}

a. $\mathrm{CFU} / \mathrm{g}=$ Colony forming units per gram of food

${ }^{\mathrm{b}}$ Not detected at dilution $10^{4}$ 
Table 3 : Climatic data and moisture content and water activity of 66 samples of freshly harvested corn kernels (hybrids BR-201, C901 e CX-322) collected in Assis, Capão Bonito and Ribeirão Preto (State of São Paulo, Brazil) from February to December 1995.

\begin{tabular}{|c|c|c|c|c|c|c|c|c|}
\hline \multicolumn{9}{|c|}{ ASSIS REGION } \\
\hline & \multicolumn{3}{|c|}{ Moisture content (\%) } & \multicolumn{3}{|c|}{ Water activity $\left(\mathrm{a}_{\mathrm{w}}\right)$} & \multirow{2}{*}{$\begin{array}{c}\text { Rainfall } \\
(\mathrm{mm})\end{array}$} & \multirow{2}{*}{$\begin{array}{c}\text { Temperature } \\
\left({ }^{\circ} \mathrm{C}\right)\end{array}$} \\
\hline & BR-201 & C-901 & CX-322 & BR-201 & C-901 & CX-322 & & \\
\hline 1 & 10.6 & 12.1 & 10.5 & 0.63 & 0.63 & 0.63 & 4.8 & 24.6 \\
\hline 2 & 11.4 & 11.8 & 11.1 & 0.63 & 0.63 & 0.62 & 5.8 & 24.8 \\
\hline 3 & 9.3 & 10.1 & 10.5 & 0.65 & 0.63 & 0.63 & 5.3 & 24.4 \\
\hline 4 & 10.9 & 11.3 & 10.2 & 0.64 & 0.62 & 0.64 & 5.6 & 24.3 \\
\hline 5 & 10.4 & 20.2 & 9.9 & 0.63 & 0.62 & 0.64 & 5.1 & 23.6 \\
\hline 6 & 6.0 & 10.0 & 5.6 & 0.53 & 0.48 & 0.50 & 5.2 & 23.3 \\
\hline 7 & 10.6 & 8.8 & 5.4 & 0.49 & 0.48 & 0.50 & 4.6 & 23.1 \\
\hline 8 & 11.8 & 6.0 & 8.8 & 0.55 & 0.49 & 0.50 & 2.7 & 21.3 \\
\hline 9 & 10.6 & 10.6 & 11.1 & 0.65 & 0.65 & 0.68 & 2.8 & 21.3 \\
\hline 10 & 10.6 & 10.6 & 11.1 & 0.65 & 0.65 & 0.68 & 4.7 & 26.1 \\
\hline \multicolumn{9}{|c|}{ CAPÃO BONITO REGION } \\
\hline & \multicolumn{3}{|c|}{ Moisture content (\%) } & \multicolumn{3}{|c|}{ Water activity $\left(a_{w}\right)$} & Rainfall & Temperature \\
\hline & BR-201 & C-901 & $\mathrm{CX}-322$ & BR-201 & C-901 & $\mathrm{CX}-322$ & $(\mathrm{~mm})$ & $\left({ }^{\circ} \mathrm{C}\right)$ \\
\hline 1 & 11.0 & 13.5 & 14.0 & 0.68 & 0.69 & 0.70 & 4.7 & 22.1 \\
\hline 3 & 10.5 & 11.6 & 10.8 & 0.61 & 0.62 & 0.30 & 5.5 & 22.2 \\
\hline 5 & 11.3 & 11.8 & 10.6 & 0.74 & 0.73 & 0.99 & 5.0 & 20.9 \\
\hline 7 & 5.0 & 16.8 & 16.2 & 0.60 & 0.54 & 0.53 & 3.0 & 19.5 \\
\hline 9 & 8.6 & 8.9 & 9.3 & 0.57 & 0.54 & 0.56 & 3.1 & 18.9 \\
\hline 11 & 11.8 & 11.3 & 10.6 & 0.61 & 0.60 & 0.62 & 2.7 & 19.0 \\
\hline \multicolumn{9}{|c|}{ RIBEIRÃO PRETO REGION } \\
\hline & \multicolumn{3}{|c|}{ Moisture content (\%) } & \multicolumn{3}{|c|}{ Water activity $\left(\mathrm{a}_{\mathrm{w}}\right)$} & Rainfall & Temperature \\
\hline & BR-201 & C-901 & CX-322 & BR-201 & C-901 & $\mathrm{CX}-322$ & $(\mathrm{~mm})$ & $\left({ }^{\circ} \mathrm{C}\right)$ \\
\hline 1 & 11.5 & 12.0 & 12.5 & 0.69 & 0.73 & 0.74 & 6.3 & 25.1 \\
\hline 3 & 10.6 & 9.6 & 10.8 & 0.65 & 0.65 & 0.65 & 7.4 & 24.7 \\
\hline 5 & 9.6 & 11.4 & 9.4 & 0.65 & 0.65 & 0.66 & 6.3 & 23.9 \\
\hline 7 & 10.6 & 11.0 & 10.3 & 0.61 & 0.61 & 0.62 & 5.2 & 23.0 \\
\hline 9 & 9.0 & 8.6 & 9.0 & 0.56 & 0.52 & 0.53 & 6.3 & 24.2 \\
\hline 11 & 9.1 & 12.2 & 9.4 & 0.59 & 0.58 & 0.58 & 6.3 & 24.2 \\
\hline
\end{tabular}

The statistical data (Table 4) of abiotic factors indicated a significant influence of $\mathrm{a}_{\mathrm{w}}$ on Fusarium spp. growth in hybrids BR-201 and CX-322 from the Assis region, and the models for these two hybrids differed significantly $(p<0.05)$. In the Capão Bonito region, a strong correlation was detected between Fusarium spp. growth and rainfall for both BR-201 e CX-322, but the analysis of parallel lines indicated a similar behavior for these two hybrids. None of the independent variables analyzed affected the growth of Fusarium spp. in cultivar C-901 in both Assis and Capão Bonito, suggesting that, in this case, some other factor(s) must be exerting an effect on the degree of fungal contamination. In the Ribeirão Preto region, a significant correlation was shown between Fusarium spp. growth and $\mathrm{a}_{\mathrm{w}}$ for hybrid BR-201 and between Fusarium spp growth and MT for both hybrids C-901 and CX-322.

An analysis of means per region showed that significant differences of Fusarium spp growth occurred in C-901 when comparing Capão Bonito with Ribeirão Preto $(\mathrm{p}<0.05)$. However, no significant regional differences were found for both BR-201 and CX-322 at the same level of significance. 
The toxigenic potential of $10 \mathrm{~A}$. flavus isolated from the 66 samples of freshly harvested corn grains (hybrids BR-201, C-901 e CX-322) was found to include 6 aflatoxin producers, with toxin concentrations ranging from $615 \mathrm{mg} / \mathrm{kg}$ to $30.750 \mathrm{mg} / \mathrm{kg}\left(\mathrm{AFB}_{1}\right)$ and from $11 \mathrm{mg} / \mathrm{kg}$ to $22 \mathrm{mg} / \mathrm{kg}\left(\mathrm{AFB}_{2}\right)$. Two $(33.3 \%)$ of these strains produced only $\mathrm{AFB}_{1}$ while 4 (66.7\%) produced both $\mathrm{AFB}_{1}$ and $\mathrm{AFB}_{2}$.

Concerning the production of fumonisins by $F$. moniliforme isolates, the data showed that all the 40 strains tested were positive for $\mathrm{FB}_{1}$ and $\mathrm{FB}_{2}$; the concentration ranged from $20 \mathrm{mg} /$ $\mathrm{g}$ to $2168 \mathrm{mg} / \mathrm{g}$ for $\mathrm{FB}_{1}$ and $10 \mathrm{mg} / \mathrm{g}$ to $380 \mathrm{mg} / \mathrm{g}$ for $\mathrm{FB}_{2}$. Out of the total analyzed, 4 strains produced only $\mathrm{FB}_{1}(10.0 \%), 2$ only $\mathrm{FB}_{2}(5.0 \%)$ and 34 both $\mathrm{FB}_{1}$ and $\mathrm{FB}_{2}(85.0 \%)$.

The highest aflatoxin and fumonisin concentrations were detected among A. flavus and F. moniliforme isolates from the Assis region; these strains were recovered from hybrids C-901 and CX-322, respectively. Such regional high production of aflatoxins and fumonisins may reflect the effect of temperature on fungal growth and consequent mycotoxins production. Lacey et al. (16) showed that the ideal temperature concerning growth and mycotoxin production ranges from 22 to $28^{\circ} \mathrm{C}$ for $F$. moniliforme strains and 25 to $35^{\circ} \mathrm{C}$ for $\mathrm{A}$. flavus strains; our temperature values recorded in the Assis region $\left(21\right.$ to $\left.26^{\circ} \mathrm{C}\right)$ fell within this range.

Although the detection of toxigenic fungi in a substrate does not necessarily indicate that mycotoxins are naturally occurring in the field, it alerts to the potential risk of contamination (4). If both the substrate and the environmental conditions are adequate for mycotoxin production, such risk may increase and reach dangerous proportions. Our data contribute to the understanding of regional factors that may influence the growth of toxigenic fungi in three different freshly harvested corn hybrids in Brazil.

\section{RESUMO}

\section{Microbiota fúngica e produção de aflatoxinas e fumonisinas por cepas de fungos isoladas de híbridos de grãos de milho recém-colhidos}

A microbiota fúngica de 66 amostras de três híbridos de grãos de milho recém-colhido, provenientes de 3 regiões do Estado de São Paulo - Brasil (Assis, Capão Bonito e Ribeirão Preto), foram analisadas perante a influência dos fatores

Table 4: Statistical model, p-value and significant variable selected for hybrids BR-201, C-901 and CX-322, collected in Assis, Capão Bonito and Ribeirão Preto (State of São Paulo, Brazil).

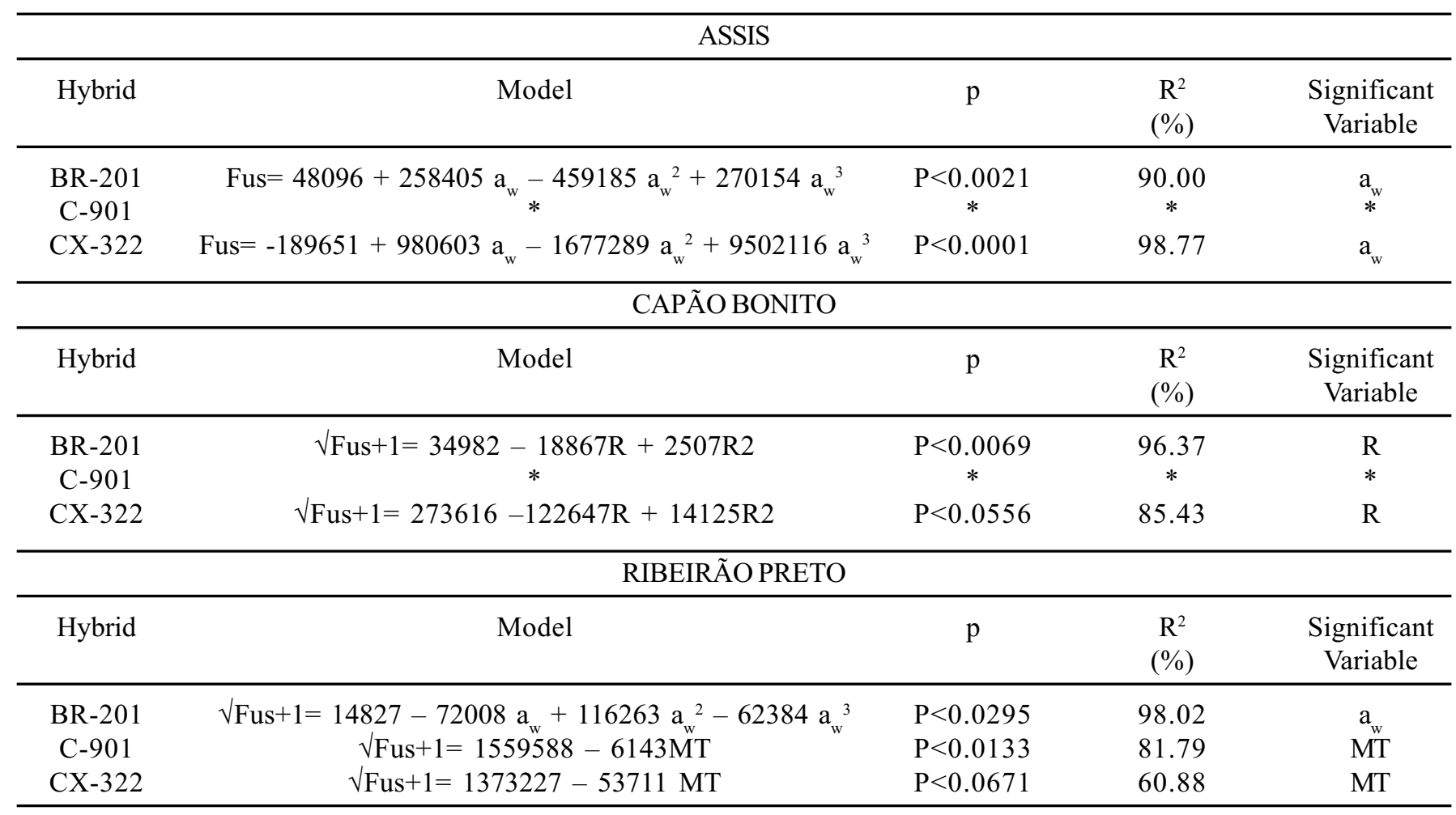

*= No model available; $\mathrm{a}_{\mathrm{w}}=$ water activity; $\mathrm{R}=$ rainfall $; \mathrm{MT}=$ mean temperature; $\mathrm{P}=\mathrm{p}$-value $; \mathrm{R}^{2}=$ correlation coefficient 
abióticos (teor de umidade, atividade de água, precipitação pluvial e temperatura média) na frequência de isolamento de fungos, bem como a potencialidade toxigênica das cepas de Aspergillus flavus e Fusarium moniliforme quanto à produção de aflatoxinas e fumonisinas, respectivamente. As análises microbiológicas demonstraram predominância de Fusarium spp., Penicillium spp. e Aspergillus spp. e outros dois gêneros de fungos filamentosos, isolados de grãos com atividade de água entre 0,30 e 0,99 e teor de umidade entre $5,0 \%$ e 20,2\%. Entre Fusarium spp, F.moniliforme foi a mais frequentemente isolada, enquanto que, em relação ao gênero Aspergillus, predominou A. flavus nas três regiões. Todas as cepas de Fusarium moniliforme isoladas (40), produziram fumonisinas, que variaram de $20 \mathrm{mg} / \mathrm{g}$ a $2168 \mathrm{mg} / \mathrm{g}\left(\mathrm{FB}_{1}\right)$ e $10 \mathrm{mg} / \mathrm{g}$ a $380 \mathrm{mg} /$ $\mathrm{g}\left(\mathrm{FB}_{2}\right)$. Referente a 10 cepas de Aspergillus flavus isoladas, 6 cepas $(60,0 \%)$ produziram aflatoxinas, que variaram de $615 \mathrm{mg} /$ $\mathrm{kg}$ a $30.750 \mathrm{mg} / \mathrm{kg}\left(\mathrm{AFB}_{1}\right)$ e $11 \mathrm{mg} / \mathrm{kg}$ a $22 \mathrm{mg} / \mathrm{kg}\left(\mathrm{AFB}_{2}\right)$.

Palavras-chave: Aflatoxinas, Aspergillus flavus, fumonisinas, Fusarium moniliforme, milho

\section{REFERENCES}

1. AOAC. Official Methods of Analysis. $3^{\mathrm{a}}$. ed. Washington, DC: Association of Analytical Chemists, 1980, 3rd. ed.

2. Barnett H.L. and Hunter B.B. Illustrated Genera of Imperfect Fungi, Minneopolis: Burgess, 1972, 3rd ed.

3. Brazilian Ministry of Agriculture. Resolution \# 845, November, 1976.

4. Bullerman L.B. Significance of mycotoxins to food safety and human health. J. Food Protection 42: 65-86, 1979.

5. Busta F.F., Petterson E.H., Adams D.M., Johnson M.G.. Colony count method. In: Compendium of methods for the microbiological examination of foods. Washington, DC: American Public Health Association, 1984, P.62-77.

6. Carvalho F.C., Ferreira C.R.R.P.T., Tsuneshiro A., Freitas S.M Avaliação econômica das perdas pós-colheita de milho no Brasil. In: XVIII Congresso Nacional de Milho e Sorgo. Vitória, 1990.

7. Castro M.F.P.M., Soares L.M.V., Furlani R.R.Z. Mycoflora, aflatoxigenic species and mycotoxins in freshly harvested corn (Zea mays L.) : a preliminary study. Rev. Microbiol. 26: 289-95, 1995.

8. Christensen C.N. and Kaufmann H.H. Grain Storage: the role of fungi quality loss. Minneapolis. University of Minnesota Press, 1969.

9. Draper N.R. and Smith H. Applied regression analysis. New York, John Wiley. 2 ed. 1981

10. Francisco V.L.F.S.F., Sueyoshi M.L.S., Pino F.A. Camargo A.M.M.P. Censo Agropecuário no Estado de São Paulo: Resultados Regionais. São Paulo, 1997.

11. González H.H.L., Resnik S.L., Boca R.T., Marasas W.F.O. Mycoflora of Argentinian corn harvest in the main production area in 1990. Mycopathologia, 130: 29-36, 1995.

12. Hill R.A., Wilson D.M., McMillian W.W., Widstron N.W., Cole R.J., Sanders T.H., Blankenship P.D. Ecology of the Aspergillus flavus group and aflatoxin formation in corn and groundnut. In: LACEY J. ed. Trichotecenes and other mycotoxins. Chichester. Wiley J., Publisher, 1985.

13. International Comission On Microbiological Specifications For Foods Microbiological ecology of foods. New York, Academic Press, 1980.

14. Joint $\mathrm{Fao} / \mathrm{Who} /$ Unep. Conference on mycotoxins. Global Perspective on mycotoxins. Nairobi, 1977.

15. Julian A.M., Warring P.W., Phillips S.I., Medlock V.F.P., Macdonald M.V., Río L.E. Fungal contamination and selected mycotoxins in pre- and post-harvest corn in Honduras. Mycopathologia 129: 5-16, 1995.

16. Lacey J., Ramakrishna N., Hamer A., Magan N., Marfleet C. Grain fungi. In: Arora, D.K.; Mukerji, K.G.; Marth, E.H. eds. - Handbook of Applied Micology: foods and feeds. New York, Marcel Dekker, 1991.

17. Leoni L.A.B. and Soares L.M.V. Desenvolvimento de uma metodologia para determinação e confirmação de moniliformina em milho. In: Congresso Latino de Micotoxicologia, 1. Encontro Nacional De Micotoxinas, 8. Rio de Janeiro, 1994, p.114-15.

18. Lillehoj E.B., Fennell D.I., Kwolek K.F. Aspergillus flavus and aflatoxin in Iowa corn before harvest. Science 495-496, 1976.

19. Lillehoj E.B., Kwolek K.F., Horner E.S., Widstrom N.M., Joséphson L.M., Franz A.O., Catalano E.A.. Aflatoxin contamination of préharvest corn: role of Aspergillus flavus inoculum and insect damage. Cereal Chem. 57: 255-257, 1980.

20. Lillehoj E.B. and Zuber M.S. Distribution of toxin-producing fungi in nature corn kernels from diverse environments. Trop. Sci. 28: 19-24, 1988.

21. Lin M.T. and Dianese J.C. A Coconut-Agar Medium for rapid detection of aflatoxin production by Aspergillus spp. Phytopathology 66: 14661469, 1976.

22. Nelson P.E., Touson T.A., Marasas W.F.O. Fusarium species. An ilustraded manual for identification. Pennsylvania, University Press, 1983, 193p.

23. Northolt M.D.and Soentoro P.S.S. Fungal growth on foodstuffs related to mycotoxin contamination. In: Samson RA, Van Reenen-Hoekstra ES, Van Dorsehot CAN eds. Introduction to Food Borne Fungi. Baars, CBS, 1988, p.231-238

24. Orsi R.B. Microbiota fúngica em 3 híbridos de milho recém-colhido e armazenado. (Dissertação de Mestrado).São Paulo: Universidade de São Paulo, 1995.

25. Orsi R.B., Corrêa B., Pozzi C, Schamass E. Mycoflora and occurrence of fumonisins in freshly harvested and stored hybrid corn. J. Stored Products Research, 36: 75-87. 2000.

26. Pedrosa A.V.B. and Dezen R.B. O milho: características do mercado e perspectivas. Preços Agrícolas 55: 1-4, 1991.

27. Pozzi C.R., Corrêa B., Gambale W., Paula C.R., Chacon-Reche N.O., Meirelles M.C.A.. Post-harvest and stored corn in Brazil: mycoflora interaction, abiotic factors and mycotoxins occurrence. Food Addit. Contam. 12: 313-19, 1995.

28. Raper K.B.and Fennell D.I. The genus Aspergillus. Baltimore: Willians \& Wilkins. 1965

29. Ross P.F., Rice L.G., Plattner R.D., Osweiler G.D., Wilson T.M., Owens D.L., Nelson H.A., Richard J.L. Concentrations of fumonisin $\mathrm{B}_{1}$ in feeds associated with animal health problems. Mycopathologia 114: 129-35, 1991.

30. Searle S.R., Casella G., McCulloch C.E. Variance components. John Wiley and Sons, Inc. 1992.

21. Tsuneshiro A., Ferreira C.R.R.P.T., Moricochi L. Produtividade da cultura do milho no Brasil: Evolução e diferenças estaduais. Agricultura em São Paulo 43: 117-35, 1996.

32. Tsuneshiro A. and Okawa H. Perspectivas da safrinha de milho em 1996. Informações Econômicas 26: 87-9, 1996. 